\title{
NOD1 Gene
}

National Cancer Institute

\section{Source}

National Cancer Institute. NOD1 Gene. NCI Thesaurus. Code C113086.

This gene plays a role in both apoptosis and immunity. 